Check for updates

Cite this: Chem. Sci., 2018, 9, 3335

Received 19th January 2018

Accepted 21st February 2018

DOI: $10.1039 / \mathrm{c} 8 \mathrm{sc} 00307 f$

rsc.li/chemical-science

\section{Simultaneous multiple single nucleotide polymorphism detection based on click chemistry combined with DNA-encoded probes $\uparrow$}

\begin{abstract}
Qian-Yu Zhou, Fang Yuan, Xiao-Hui Zhang, Ying-Lin Zhou (D) * and Xin-Xiang Zhang*
Single nucleotide polymorphisms (SNPs) are emerging as important biomarkers for disease diagnosis, prognostics and disease pathogenesis. As one type of disease is always connected to several SNP sites, there is great demand for a reliable multiple SNP detection method. Herein, we mimicked a ligation reaction based on DNA ligase and originally utilized an enzyme-free DNA template-directed click reaction for SNP detection. With $5^{\prime}$-alkyne and $3^{\prime}$-azide groups labelled on two oligonucleotide probes, the target DNA-directed $\mathrm{Cu}(\mathrm{I})$-catalyzed alkyne-azide cycloaddition (CuAAC) click reaction produced a new DNA strand with a triazole backbone, as a mimic of a DNA phosphodiester linkage. Trace amounts of the target (as low as $25 \mathrm{fmol}$ in $50 \mu \mathrm{L}$ ) could be sensitively detected using capillary gel electrophoresis with laser-induced fluorescence (CGE-LIF). Meanwhile, SNP caused an obvious difference in the efficiency of the click reaction, and $0.5 \%$ SNP could be easily detected. More importantly, multiplexed SNP detection in a one tube reaction was successfully achieved only by encoding different lengths of the DNA probes for the different SNP sites.
\end{abstract}

\section{Introduction}

Single nucleotide polymorphism (SNP) refers to a single base variation in the genomic sequence. ${ }^{1,2}$ It consists of singlenucleotide substitutions, insertions and deletions. It is the most common variant of human genetic variation. ${ }^{3}$ The detection of SNP is important for disease diagnosis, prognostics and disease pathogenesis. ${ }^{4,5} \mathrm{~A}$ series of various technologies have been developed for SNP genotyping: ${ }^{6-12}$ Among these methods, a ligation-dependent method performs as a highly sensitive and selective platform for the detection of SNP based on the specificity of the DNA ligase. ${ }^{13-16}$ However, enzymatic techniques usually require a strict environment and the operation is complex, which might hinder their use in clinical diagnosis, especially at point-of-care detection. Recently, non-enzymatic template-directed chemical reactions, ${ }^{17-20}$ such as nucleophilic substitution, cycloaddition and condensation, have shown great potential in the detection of DNA and RNA. Without the use of an enzyme, these methods can be used for the direct detection of nucleic acids in a complex matrix without sample preparation or target isolation. ${ }^{21,22}$ Furthermore, enzymatic methods cannot work in intact cells since it is difficult to deliver

Beijing National Laboratory for Molecular Sciences (BNLMS), MOE Key Laboratory of Bioorganic Chemistry and Molecular Engineering, College of Chemistry, Peking University, Beijing 100871, China. E-mail: zhouyl@pku.edu.cn; zxx@pku.edu.cn; Fax: +86-10-62754112; Tel: +86-10-62754112

$\dagger$ Electronic supplementary information (ESI) available. See DOI: $10.1039 / \mathrm{c} 8 \mathrm{sc} 00307 \mathrm{f}$ enzymes into cells, while these non-enzymatic approaches are robust and effective for their use in cells..$^{23,24}$

Click chemistry ${ }^{25-27}$ is a simple and rapid synthetic method based on the carbon-heteroatom bond. The best example of click chemistry is the $\mathrm{Cu}(\mathrm{I})$-catalyzed alkyne-azide cycloaddition (CuAAC) reaction. This reaction has the virtues of fast reaction speed, high yield of product and mild reaction conditions. Therefore, it is widely used in many fields such as proteomics, ${ }^{28}$ surface modification ${ }^{29}$ and biomedicine. ${ }^{30}$ Much research about oligonucleotide labelling using the CuAAC reaction has been reported. ${ }^{31-35}$ Brown et al. applied the CuAAC reaction to synthesize a covalently closed ssDNA circle and a dsDNA pseudohexagon, thereby constructing DNA nanotechnology. ${ }^{31}$ They then synthesized very long oligonucleotides using the CuAAC reaction and demonstrated that the artificial linkage was still functional in bacterial and human cells. ${ }^{32,36}$ With these advantages, the CuAAC reaction might be an excellent chemical ligation strategy to simulate the action of DNA ligase.

Generally, one type of disease is always connected to several SNP sites. ${ }^{37}$ Lung cancer is associated with multiple genes such as EGFR, ALK, MET and so on. ${ }^{38}$ The simultaneous multiple SNP detection for one type of disease can not only improve the accuracy of the diagnosis, but also provide some guidance for individualized targeted therapy. With the increasing attention on genome-wide linkage studies, more research focuses on the identification of the genetic variants related to complex diseases and traits. ${ }^{39,40}$ On this basis the construction of multiplex SNP genotyping methods can be an efficient and applicable approach for the detection of genes associated with the 
occurrence, development and treatment of disease. ${ }^{\mathbf{4 1 , 4 2}}$ Meanwhile, the multiplex detection of SNPs can not only reduce the cost of genotyping, but also avoid tedious repeat operations. However, except DNA sequencing, ${ }^{\mathbf{4 3 4 4}}$ most of the developed techniques for SNP detection lack multiplex detection abilities. DNA sequencing methods suffer from time-consuming procedures and expensive costs. Some fluorescence-based techniques ${ }^{\mathbf{4 5 , 4 6}}$ have been developed for multiplex SNP detection, but their high-throughput is limited by the number of distinct fluorescent reporters, and spectral overlap cannot be avoided. Mass spectrometry based methods ${ }^{47,48}$ are limited by expensive instruments and the difficulty of the use of large-scale equipment for clinical testing. Capillary electrophoresis $(\mathrm{CE})^{\mathbf{4 9 - 5 1}}$ has been used for the multiplex detection of nucleic acids. The capability of CE for multiplex detection is related to its highly effective separation ability, so it can easily achieve real highthroughput detection.

Herein we have proposed a novel strategy for the first SNP discrimination based on CuAAC click chemistry combined with capillary gel electrophoresis with laser-induced fluorescence detection (CGE-LIF). Because of the high sequence specificity of the chemical reaction, SNP can be easily detected through the efficiency of the click reaction. Moreover, by encoding different lengths for the DNA probes for the different SNP sites, the ligated products produced by the CuAAC reaction can be simply separated using CGE. Therefore, multiplexed SNP detection in a one tube reaction can be easily achieved.

\section{Results and discussion}

\section{The principle of CuAAC-based multiplexed SNP detection}

The design principle for the detection of multiplexed SNP is illustrated in Scheme 1. The probes $P_{M}$ and $P_{N}$ are designed to hybridize to a DNA target, wherein the probe $\mathrm{P}_{\mathrm{M}}$ is modified with a fluorescent group FAM at the $5^{\prime}$ end and an azide group at the $3^{\prime}$ end, while an alkynyl group is modified at the $5^{\prime}$ end of the probe $\mathrm{P}_{\mathrm{N}}$. Due to the relatively low concentrations of the probes, the ligation reaction caused by the free collision of two groups on the probes does not proceed easily in the absence of a perfectly matched target $(\mathrm{T})$. However, in the presence of $\mathrm{T}$, the two probes are induced to approach each other through hybridizing with $\mathrm{T}$, and can be easily ligated through the CuAAC reaction. A singlebase mismatched target (M) leads to a thermodynamic difference between the probe strands and $\mathbf{M}$, which inhibits the formation of stable hybrid double chains. Due to the steric effects of these reactive groups, little ligation occurs. Furthermore, through the design of different lengths for the probes, the CuAAC reactions will yield FAM-labeled DNA strands with different lengths for the different SNP sites. The products can be easily separated using CGE and fluorophore labeled DNA can be detected by the LIF detection. Hence, multiplex SNP detection can be easily realized in a one-tube CuAAC reaction.

\section{The feasibility of the CuAAC-based SNP assay}

The performances of the probes $\mathrm{P}_{\mathrm{M}}$ and $\mathrm{P}_{\mathrm{N}}$ in the absence of $\mathrm{T}$ and in the presence of $\mathrm{T}$ and $\mathrm{M} 3$ (the sequences are illustrated

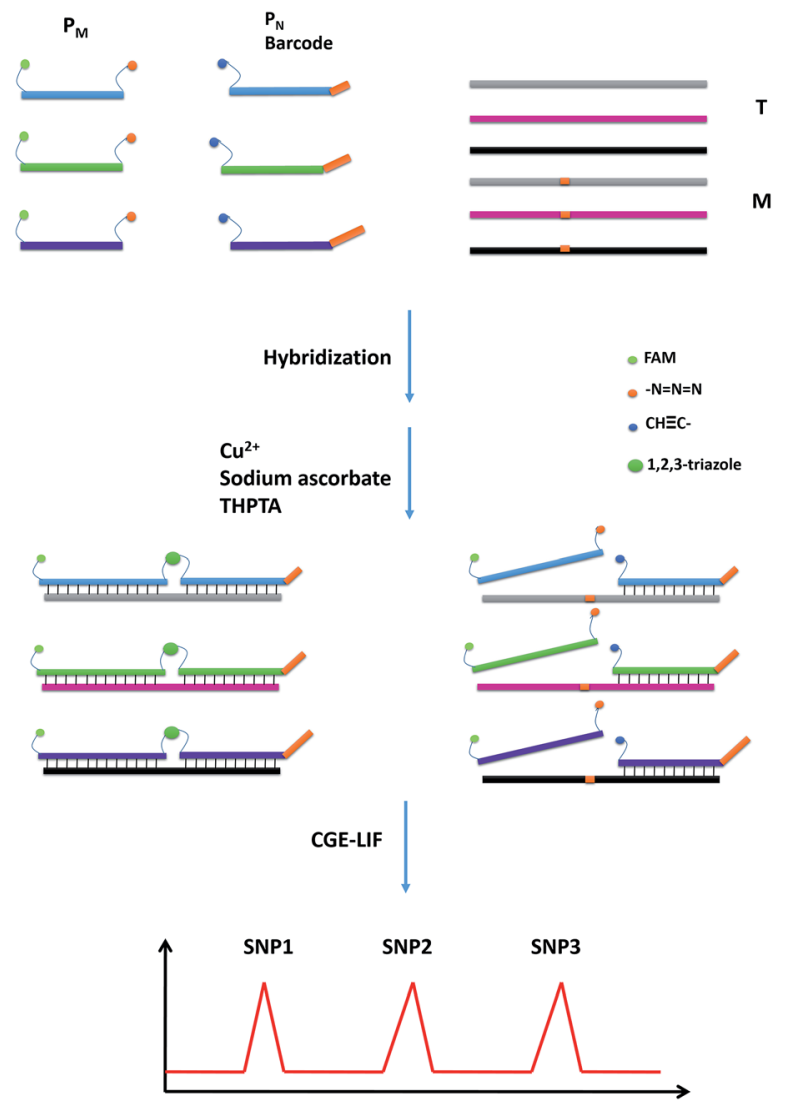

Scheme 1 The schematic principle of CUAAC-based multiplexed SNP detection.

in Table $\mathrm{S} 1 \dagger$ ) were investigated using CGE-LIF. As shown in Fig. 1, there are three peaks in the electropherograms. The retention time is related to the length of the oligonucleotide. The longer the length of the oligonucleotide, the later the retention time is. Peak 1 is attributed to an internal standard with a length of four bases, which is used to correct the peak areas of the products caused by an uncertainty of the sample

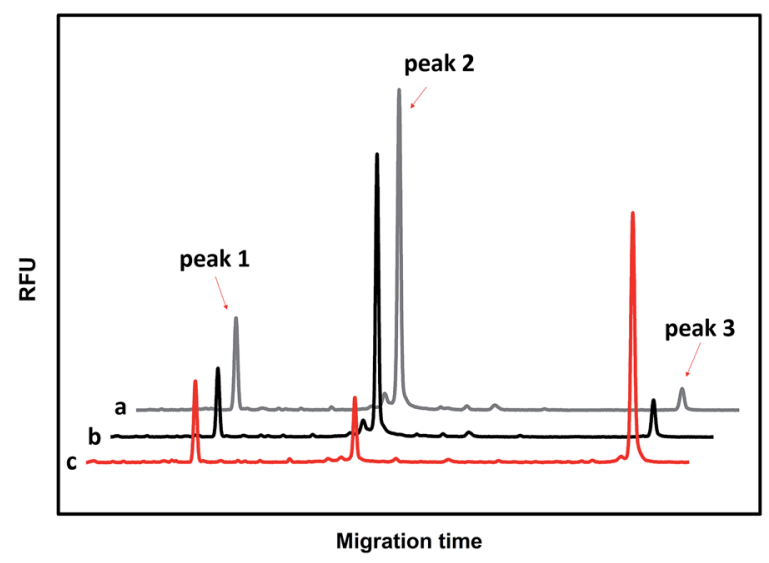

Fig. 1 Electropherograms for the feasibility of CuAAC-based SNP detection. (a) $50 n M P_{M}+50 n M P_{N}$; (b) $50 n M P_{M}+50 n M P_{N}+100 n M$ M3; (c) $50 n M P_{M}+50 n M P_{N}+100 n M T$. 
injection amount. Peak 2 is attributed to unreacted $\mathrm{P}_{\mathbf{M}}$. Peak 3 corresponds to the product of the click reaction between $\mathrm{P}_{\mathrm{M}}$ and $\mathrm{P}_{\mathrm{N}}$. In the absence of the DNA target, peak 3 is very small (Fig. 1a), indicating that the efficiency of the click reaction is quite low for the free collision of the probes $\mathrm{P}_{\mathrm{M}}$ and $\mathrm{P}_{\mathrm{N}}$ in solution. When comparing the electropherograms $b$ and $c$ with a, it can be seen that the addition of M3 only causes a small amount of the probes to be connected, while the addition of $\mathrm{T}$ can yield a large number of ligation products due to the stability of the duplex among $\mathrm{P}_{\mathrm{M}}, \mathrm{P}_{\mathrm{N}}$ and the target. HPLC-ESI-MS was conducted to further verify the formation of the ligation products. As shown in Fig. $\mathrm{S} 1, \dagger$ in the absence of $\mathrm{T}$ or in the presence of $\mathrm{M} 3$, we could only find peaks corresponding to $\mathrm{P}_{\mathrm{M}}$ and $\mathrm{P}_{\mathrm{N}}$ according to their molecular weight, while in the presence of $\mathrm{T}$ another peak belonging to the ligation product appeared, which indicated the successful ligation between $\mathrm{P}_{\mathrm{M}}$ and $\mathrm{P}_{\mathrm{N}}$ directed by T. Therefore, the assay has a good ability to discriminate between $\mathrm{T}$ and $\mathrm{M}$, indicating that it can be used to detect the SNPs.

\section{Optimization of the experimental conditions}

In order to obtain optimal conditions for the CuAAC-based SNP assays, we investigated several reaction conditions which might influence the SNP discrimination ability. To utilize the sequence specificity of the DNA strands, an important factor is the discrimination ability to identify SNP at different positions relative to the template-directed click reaction site. Different DNA templates (Table $\mathrm{S} 1 \dagger$ ) with a single-base mutation at the different positions $\mathrm{N}_{1}$ to $\mathrm{N}_{4}$ (denoted as M1-M7) (Scheme 2) were designed. Since the type of base-mismatch has a big influence on SNP discrimination, ${ }^{52}$ to compare the site of the mismatch on the SNP discrimination ability, two different sites were compared by adjusting the base type of $\mathrm{N}_{x}$ and making the base pairs of the two mutation sites the same. As shown in Table $\mathrm{S} 3, \uparrow$ the results for the SNP discrimination based on a targetdirected click reaction demonstrate site-dependent effects. By calculating the relative peak area observed with the $\mathrm{N}_{x}$-mismatched strands of the four sites, substitution of the base at the $\mathrm{N}_{3}$ position resulted in the lowest efficiency of the click reaction. Therefore, single-base mutation at the $\mathrm{N}_{3}$ position holds great potential for the detection of SNP.

The effects of temperature on the connection efficiency of the CuAAC reaction caused by $\mathrm{T}$ and $\mathrm{M} 3$ were also investigated (using $\mathrm{G}>\mathrm{C}$ substitution at the $\mathrm{N}_{3}$ position as a model). The melting temperatures $\left(T_{\mathrm{m}}\right)$ of the probes $\mathrm{P}_{\mathrm{M}}$ and $\mathrm{P}_{\mathrm{N}}$ were found to be $25^{\circ} \mathrm{C}$ and $29.1^{\circ} \mathrm{C}$, respectively. As shown in Fig. S2, $\dagger$ it was found that the connection efficiency for both $\mathrm{T}$ and $\mathrm{M} 3$ decreases with the increase of the temperature, indicating that the stability of the duplex between $\mathrm{P}_{\mathrm{M}}, \mathrm{P}_{\mathrm{N}}$ and the target is

A-T-C-G-A-A-T- $\mathrm{N}_{4}-\mathrm{N}_{3}-\mathrm{N}_{2}-\mathrm{N}_{1}-\mathrm{T}-\mathrm{G}-\mathrm{A}-\mathrm{C}-\mathrm{T}-\mathrm{A}-\mathrm{C}-\mathrm{A}-\mathrm{A}-\mathrm{C}-\mathrm{T}$ FAM-T-A-G-C-T-T-A-T---C--A---G A-C-T-G-A-T-G-T-T-G-A $\mathrm{N}_{3} \quad \mathrm{C}=\mathrm{CH}$

Scheme 2 An image of DNA-directed reactions in the presence of a single-base mutation at the different positions $N_{1}$ to $N_{4}$. related to the reaction temperature. The best selectivity for SNP was achieved when the reaction was performed at $30^{\circ} \mathrm{C}$, which is slightly higher than the $T_{\mathrm{m}}$ of the probes.

The incremental ratio of the fluorescence intensity for the CuAAC product in the presence of $\mathrm{T}$ relative to that with $\mathrm{M} 3$ is plotted against the reaction probe ratio $\left(\mathrm{P}_{\mathrm{M}}: \mathrm{P}_{\mathrm{N}}\right)$ and the reaction time (Fig. S3 and $\mathrm{S} 4 \dagger$ ). When the amount of $\mathrm{P}_{\mathrm{N}}$ gradually increases, the degree of discrimination becomes better. It is possible that the probe $\mathrm{P}_{\mathrm{M}}$, which has a mutation base, is unstable for $\mathrm{M} 3$ at the reaction temperature, while the probe $\mathrm{P}_{\mathrm{N}}$ is stable for T or M3. So if the amount of the probe $P_{N}$ increases, there are more $\mathrm{P}_{\mathrm{N}}$ chains that can be hybridized to the small amount of $\mathrm{T}$. In this case, the probes $\mathrm{P}_{\mathrm{M}}$ and $\mathrm{P}_{\mathrm{N}}$ are more likely to be ligated with chemical reaction in the presence of $P_{M}$. Finally, the probe reaction ratio of $\mathrm{P}_{\mathrm{M}}: \mathrm{P}_{\mathrm{N}}=1: 10$ was used as the reaction condition. The reaction time is another important factor for SNP detection. As shown in Fig. S4, $\uparrow$ the discrimination effect is best at the reaction time of $30 \mathrm{~min}$.

\section{Analytical performance of the CuAAC-based assay}

To evaluate the sensitivity of the CuAAC-based assay, we used $\mathrm{T}$ as the model. As demonstrated in Fig. 2, as the concentration of $\mathrm{T}$ increases, the fluorescence of the CuAAC products increases. There is a good linear relationship between the RPA and the T concentration ranging from $500 \mathrm{pM}$ to $10 \mathrm{nM}(\mathrm{RPA}=0.17 \times$ $\left.c_{\mathrm{T}}+0.093, R^{2}=0.99\right)$. When the amount of $\mathrm{T}$ is as low as $25 \mathrm{fmol}$ in $50 \mu \mathrm{L}$, it can still be sensitively detected, indicating that the CuAAC-based assay can be used for the quantification of the DNA target.

To investigate the selectivity of the assay for SNP detection, we applied this method to detect a low abundance of $\mathrm{T}$ in the presence of different amounts of different mismatched targets M. As demonstrated in Table $\mathrm{S} 1, \dagger$ we used the DNA probes to detect different base-mismatched types at the site $\mathrm{N}_{3}$. T was mixed with different mismatched targets $\mathrm{M}$ (M3, M4 or M5) at

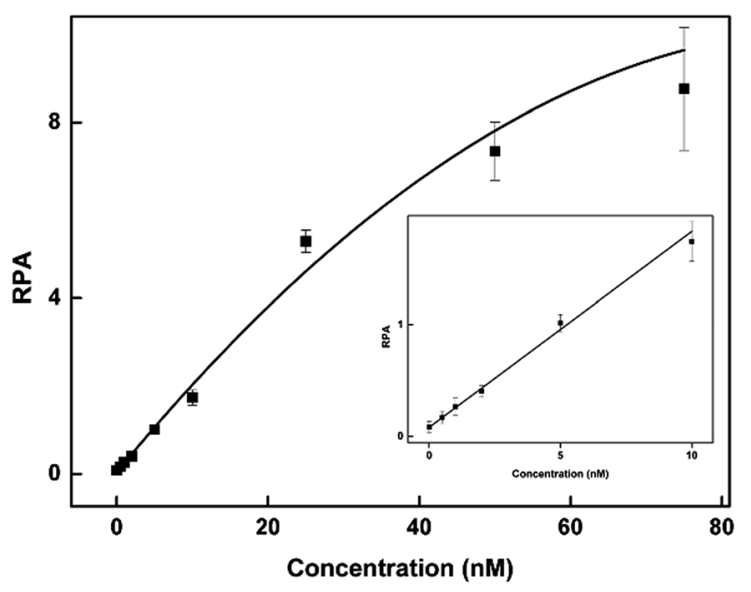

Fig. 2 The corresponding calibration plot of RPA vs. the concentration of $\mathrm{T}$. The inset is the linear part of the plot of RPA vs. the concentration of $\mathrm{T}$. The concentration of $\mathrm{T}$ ranges from $500 \mathrm{pM}$ to $10 \mathrm{nM}$. The standard deviation of three parallel experiments determined the error bar. 
abundances of $0 \%, 0.5 \%, 1 \%, 5 \%, 10 \%$ and $100 \%$. The sample mixtures were detected by the CuAAC-based assay using $\mathrm{P}_{\mathrm{M}}$ and $\mathrm{P}_{\mathrm{N}}$ as probes. The electropherograms for the detection of the $\mathrm{C}$ : C mismatched target in the probe/target hybrids ( $\mathrm{G}>\mathrm{C}$ substitution) is shown in Fig. 3A. The data shown in Fig. 3B were converted from the data shown in Fig. 3A by calculation of the fluorescence. As demonstrated in Fig. 3A and B, T can be obviously identified at an abundance of as low as $0.5 \%$ in the presence of a large amount of M3. Similarly, as low as $0.5 \%$ of the $\mathrm{C}: \mathrm{A}$ and $\mathrm{C}: \mathrm{T}$ mismatches in the probe/target hybrids can also be clearly detected using the CuAAC-based assay (Fig. 3B).

\section{Multiplexed SNP detection}

Since SNPs have been used as molecular markers in clinical diagnosis and pharmacogenomic studies, the rapid, automated, accurate and affordable detection of SNPs is important.

To assess the multiplexing performance of this assay for SNP detection, the STK11 gene, which is associated with PeutzJeghers syndrome, ${ }^{\mathbf{5 3}, 54}$ was used as the detection target. PeutzJeghers syndrome is a kind of dominant genetic disease. The early diagnosis and prognosis of the disease can improve the quality of life of and reduce the mortality of patients. Since electrophoresis has the excellent ability to separate different
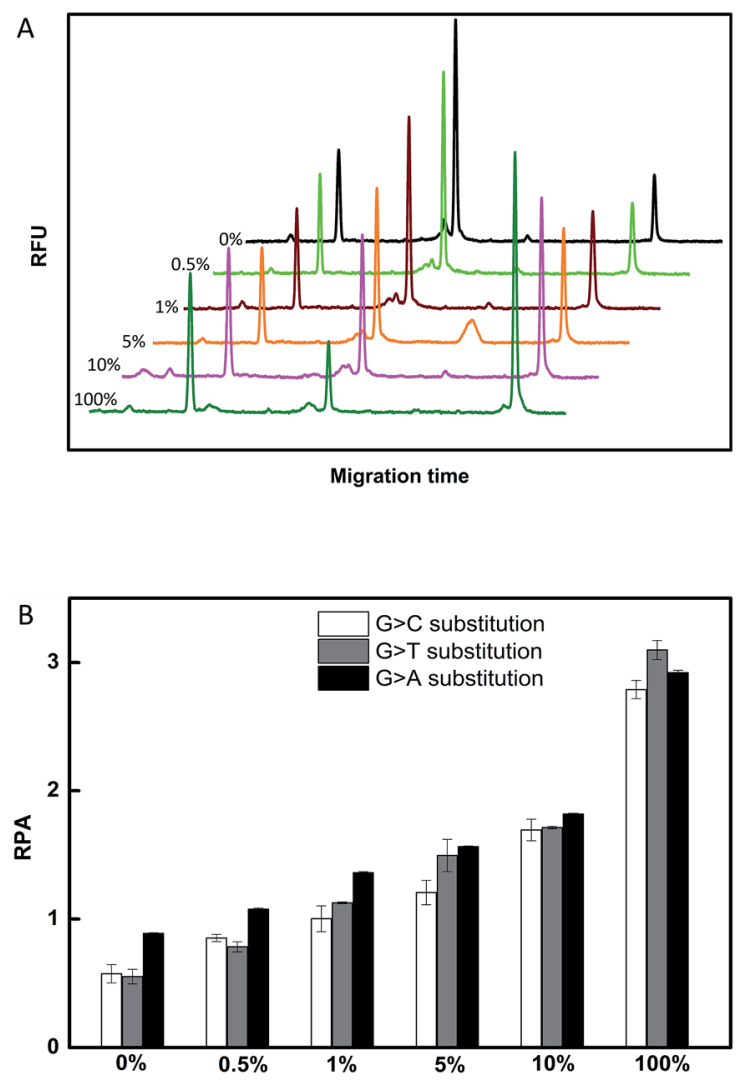

Fig. 3 (A) The electropherograms for the detection of different abundances of $T$ with $M 3$ ( $G>C$ substitution). (B) The histogram of the CuAAC-based assay for different abundances of $T$ with $M 3$ ( $G>C$ substitution), M4 ( $G>T$ substitution), and M5 ( $G>A$ substitution). The standard deviation of three parallel experiments determined the error bar.
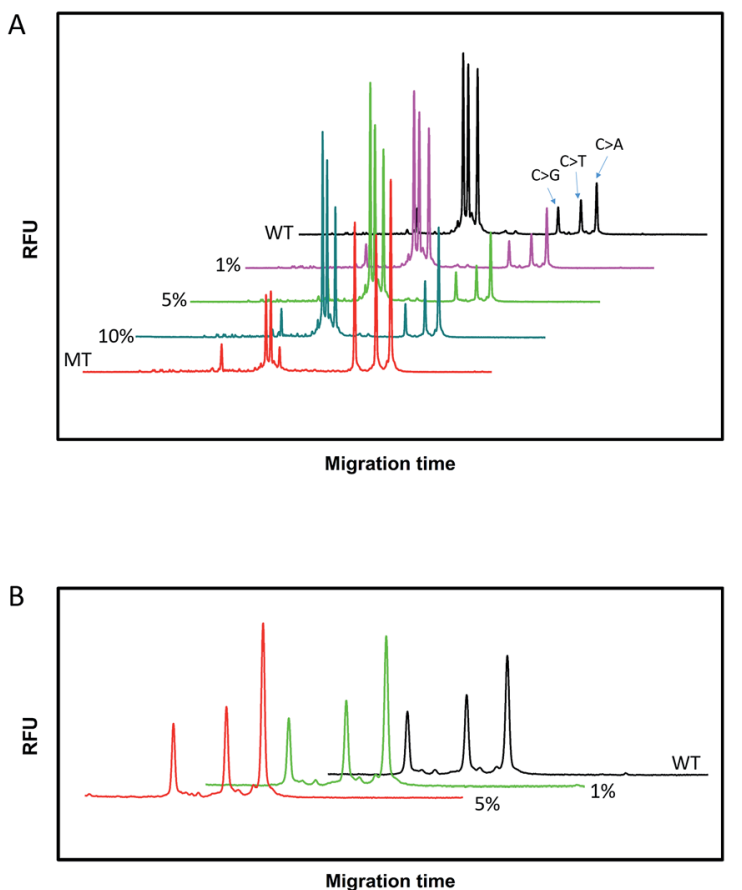

Fig. 4 The electropherograms for the multiplexed SNP discrimination in the detection of STK11 gene $(C>G, C>T$, and $C>A)$ using the CuAAC-based assay at different abundances (A), and at low abundances $(0-5 \%)$ in an enlarged scale (B). WT means the tested sequences are all wild type targets. MT means the tested sequences are all mutant type targets.

lengths of oligonucleotides, a CuAAC-based assay can achieve multiplex detection only by simply encoding the DNA probes with different lengths. Three specific probes for the STK11 gene, rs59912467C > G(WT $\left./ \mathrm{MT}_{1}\right)$, rs184528337C $>\mathrm{T}\left(\mathrm{WT}_{2} / \mathrm{MT}_{2}\right)$, and rs587778695C $>\mathrm{A}\left(\mathrm{WT}_{3} / \mathrm{MT}_{3}\right)$, were designed. The lengths of the DNA probes were adjusted with random deoxynucleotide, which has no interference with the hybridization between the DNA probes and the targets. Accordingly, the total length of the FAMlabeled $\mathrm{P}_{\mathrm{M} 1}$ and $\mathrm{P}_{\mathrm{N} 1}$ is 20 nucleotides (nts) for target $\mathrm{MT}_{1}$, $\mathrm{P}_{\mathrm{M} 2} \mathrm{P}_{\mathrm{N} 2}$ is 24 nts for target $\mathrm{MT}_{2}$, and $\mathrm{P}_{\mathrm{M} 3} \mathrm{P}_{\mathrm{N} 3}$ is $26 \mathrm{nts}$ for target $\mathrm{MT}_{3}$. The all mutant type targets were mixed with wild type targets at abundances of $0 \%$ (the tested sequences were all wild type targets), $1 \%, 5 \%, 10 \%$ and $100 \%$ (the tested sequences were all mutant type targets). Then the sample mixtures were detected using the CuAAC-based assay in one-tube using the mixed specific probes. As shown in Fig. 4, the different lengths of the FAM-labeled products can be well separated and clearly detected. More importantly, the different mutant type targets can still be identified at an abundance of as low as 1\% even under the complex conditions, which is better than those reported by some other methods for multiple SNP detection. ${ }^{45,48,55-57}$ Therefore, the CuAAC-based assay can be well used for the multiplex detection of SNPs.

\section{Conclusions}

In summary, we have established a novel method for SNP discrimination using CuAAC-based assays. The enzyme-free 
click chemical ligation between $\mathrm{N}_{3}$-DNA and $\mathrm{CH} \equiv \mathrm{C}$-DNA makes the assay simple and robust without the need for special separation and purification. The SNP can be sensitively discriminated and the mutant type target can be identified at an abundance of as low as $0.5 \%$ in the presence of a wild type target. Moreover, the multiplexed analysis of SNP detection can be easily realized by simply encoding DNA probes of different lengths with the CuAAC-based assays. Therefore, we believe that this CuAAC-based SNP assay has great potential for clinical application.

\section{Conflicts of interest}

There are no conflicts to declare.

\section{Acknowledgements}

This work was supported by the National Natural Science Foundation of China (No. 21675004 and 21575005).

\section{Notes and references}

1 A. J. Brookes, Gene, 1999, 234, 177-186.

2 The International SNP Map Working Group, Nature, 2001, 409, 928-933.

3 C. Genomes Project, G. R. Abecasis, D. Altshuler, A. Auton, L. D.Brooks, R. M. Durbin, R. A. Gibbs, M. E. Hurles and G. A. McVean, Nature, 2010, 467, 1061-1073.

4 G. Siravegna and A. Bardelli, Mol. Oncol., 2016, 10, 475-480. 5 S. Tuupanen, M. Turunen, R. Lehtonen, O. Hallikas, S. Vanharanta, T. Kivioja, M. Bjorklund, G. Wei, J. Yan, I. Niittymaki, J. P. Mecklin, H. Jarvinen, A. Ristimaki, M. Di-Bernardo, P. East, L. Carvajal-Carmona, R. S. Houlston, I. Tomlinson, K. Palin, E. Ukkonen, A. Karhu, J. Taipale and L. A. Aaltonen, Nat. Genet., 2009, 41, 885-890.

6 J. Zhang, X. Wu, P. Chen, N. Lin, J. Chen, G. Chen and F. Fu, Chem. Commun., 2010, 46, 6986-6988.

7 X. Xiao, C. Zhang, X. Su, C. Song and M. Zhao, Chem. Sci., 2012, 3, 2257-2261.

8 T. Wu, X. Xiao, Z. Zhang and M. Zhao, Chem. Sci., 2015, 6, 1206-1211.

9 X. Xiao, T. Wu, F. Gu and M. Zhao, Chem. Sci., 2016, 7, 20512057.

10 S. Hu, W. Tang, Y. Zhao, N. Li and F. Liu, Chem. Sci., 2017, 8, 1021-1026.

11 J. M. Obliosca, S. Y. Cheng, Y. A. Chen, M. F. Llanos, Y. L. Liu, D. M. Imphean, D. R. Bell, J. T. Petty, P. Ren and H. C. Yeh, J. Am. Chem. Soc., 2017, 139, 7110-7116.

12 S. Nakayama, L. Yan and H. O. Sintim, J. Am. Chem. Soc., 2008, 130, 12560-12561.

13 Y. S. Huh, A. J. Lowe, A. D. Strickland, C. A. Batt and D. Erickson, J. Am. Chem. Soc., 2009, 131, 2208-2213.

14 W. Shen, H. Deng, A. K. Teo and Z. Gao, Chem. Commun., 2012, 48, 10225-10227.

15 F. Su, L. Wang, Y. Sun, C. Liu, X. Duan and Z. Li, Chem. Sci., 2015, 6, 1866-1872.
16 D. Al Sulaiman, J. Y. H. Chang and S. Ladame, Angew. Chem., Int. Ed., 2017, 56, 5247-5251.

17 Y. Z. Xu, N. B. Karalkar and E. T. Kool, Nat. Biotechnol., 2001, 19, 148-152.

18 A. Kern and O. Seitz, Chem. Sci., 2015, 6, 724-728.

19 E. M. Harcourt and E. T. Kool, Nucleic Acids Res., 2012, 40, e65.

20 M. Rothlingshofer, K. Gorska and N. Winssinger, J. Am. Chem. Soc., 2011, 133, 18110-18113.

21 W. A. Velema and E. T. Kool, J. Am. Chem. Soc., 2017, 139, 5405-5411.

22 H. Wu, B. T. Cisneros, C. M. Cole and N. K. Devaraj, J. Am. Chem. Soc., 2014, 136, 17942-17945.

23 H. Wu, S. C. Alexander, S. Jin and N. K. Devaraj, J. Am. Chem. Soc., 2016, 138, 11429-11432.

24 R. M. Franzini and E. T. Kool, J. Am. Chem. Soc., 2009, 131, 16021-16023.

25 R. Huisgen, Angew. Chem., Int. Ed., 1963, 2, 565-598.

26 H. C. Kolb, M. G. Finn and K. B. Sharpless, Angew. Chem., Int. Ed., 2001, 40, 2004-2021.

27 V. V. Rostovtsev, L. G. Green, V. V. Fokin and K. B. Sharpless, Angew. Chem., Int. Ed., 2002, 41, 2708-2711.

$28 \mathrm{~W}$. H. Binder and R. Sachsenhofer, Macromol. Rapid Commun., 2007, 28, 15-54.

29 C. D. Hein, X. M. Liu and D. Wang, Pharm. Res., 2008, 25, 2216-2230.

30 K. Nwe and M. W. Brechbiel, Cancer Biother.Radiopharm., 2009, 24, 289-302.

31 R. Kumar, A. El-Sagheer, J. Tumpane, P. Lincoln, L. M. Wilhelmsson and T. Brown, J. Am. Chem. Soc., 2007, 129, 6859-6864.

32 A. H. El-Sagheer, A. P. Sanzone, R. Gao, A. Tavassoli and T. Brown, Proc. Natl. Acad. Sci. U. S. A., 2011, 108, 1133811343.

33 J. Qiu, A. H. El-Sagheer and T. Brown, Chem. Commun., 2013, 49, 6959-6961.

34 Y. Zhou, S. Wang, K. Zhang and X. Jiang, Angew. Chem., Int. Ed., 2008, 47, 7454-7456.

35 Y. Chen, Y. Xianyu, J. Wu, B. Yin and X. Jiang, Theranostics, 2016, 6, 969-985.

36 C. N. Birts, A. P. Sanzone, A. H. El-Sagheer, J. P. Blaydes, T. Brown and A. Tavassoli, Angew. Chem., Int. Ed., 2014, 53, 2362-2365.

37 J. De Greve, E. Teugels, C. Geers, L. Decoster, D. Galdermans, J. De Mey, H. Everaert, I. Umelo, P. In't Veld and D. Schallier, Lung Canc., 2012, 76, 123-127.

38 G. J. Korpanty, D. M. Graham, M. D. Vincent and N. B. Leighl, Front. Oncol., 2014, 4, 204.

39 E. Huerta-Sanchez, X. Jin, Asan, Z. Bianba, B. M. Peter, N. Vinckenbosch, Y. Liang, X. Yi, M. He, M. Somel, P. Ni, B. Wang, X. Ou, Huasang, J. Luosang, Z. X. Cuo, K. Li, G. Gao, Y. Yin, W. Wang, X. Zhang, X. Xu, H. Yang, Y. Li, J. Wang, J. Wang and R. Nielsen, Nature, 2014, 512, 194-197.

40 R. Beroukhim, C. H. Mermel, D. Porter, G. Wei, S. Raychaudhuri, J. Donovan, J. Barretina, J. S. Boehm, J. Dobson, M. Urashima, K. T. Mc Henry, R. M. Pinchback, A. H. Ligon, Y.-J. Cho, L. Haery, H. Greulich, M. Reich, 
W. Winckler, M. S. Lawrence, B. A. Weir, K. E. Tanaka, D. Y. Chiang, A. J. Bass, A. Loo, C. Hoffman, J. Prensner, T. Liefeld, Q. Gao, D. Yecies, S. Signoretti, E. Maher, F. J. Kaye, H. Sasaki, J. E. Tepper, J. A. Fletcher, J. Tabernero, J. Baselga, M.-S. Tsao, F. DeMichelis, M. A. Rubin, P. A. Janne, M. J. Daly, C. Nucera, R. L. Levine, B. L. Ebert, S. Gabriel, A. K. Rustgi, C. R. Antonescu, M. Ladanyi, A. Letai, L. A. Garraway, M. Loda, D. G. Beer, L. D. True, A. Okamoto, S. L. Pomeroy, S. Singer, T. R. Golub, E. S. Lander, G. Getz, W. R. Sellers and M. Meyerson, Nature, 2010, 463, 899-905. 41 L. Lieben, Nat. Rev. Genet., 2016, 17, 4.

42 Z. Wang, A. D. Sadovnick, A. L. Traboulsee, J. P. Ross, C. Q. Bernales, M. Encarnacion, I. M. Yee, M. de Lemos, T. Greenwood, J. D. Lee, G. Wright, C. J. Ross, S. Zhang, W. Song and C. Vilarino-Guell, Neuron, 2016, 92, 555.

43 E. R. Mardis, Annu. Rev. Genomics Hum. Genet., 2008, 9, 387402.

44 M. W. Schmitt, S. R. Kennedy, J. J. Salk, E. J. Fox, J. B. Hiatt and L. A. Loeb, Proc. Natl. Acad. Sci. U. S. A., 2012, 109, 14508-14513.

45 J. Song, J. Zhang, F. Lv, Y. Cheng, B. Wang, L. Feng, L. Liu and S. Wang, Angew. Chem., Int. Ed., 2013, 52, 13020-13023. 46 Z. Jin, D. Geissler, X. Qiu, K. D. Wegner and N. Hildebrandt, Angew. Chem., Int. Ed., 2015, 54, 10024-10029.
47 N. O. Meyer, A. J. O'Donoghue, U. Schulze-Gahmen, M. Ravalin, S. M. Moss, M. B. Winter, G. M. Knudsen and C. S. Craik, Anal. Chem., 2017, 89, 4550-4558.

48 J. H. Park, H. Jang, Y. K. Jung, Y. L. Jung, I. Shin, D. Y. Cho and H. G. Park, Biosens. Bioelectron., 2017, 91, 122-127.

49 W. Choi and G. Y. Jung, Electrophoresis, 2017, 38, 513-520.

50 D. W. Wegman and S. N. Krylov, Angew. Chem., Int. Ed., 2011, 50, 10335-10339.

51 P. Zhang, Y. Liu, Y. Zhang, C. Liu, Z. Wang and Z. Li, Chem. Commun., 2013, 49, 10013-10015.

52 S. Ikuta, K. Takagi, R. B. Wallace and K. Itakura, Nucleic Acids Res., 1987, 15, 797-811.

53 D. E. Jenne, H. Reimann, J.-I. Nezu, W. Friedel, S. Loff, R. Jeschke, O. Mueller, W. Back and M. Zimmer, Nat. Genet., 1998, 18, 38-43.

54 J.-H. Chen, J.-J. Zheng, Q. Guo, C. Liu, B. Luo, S.-B. Tang, J.-D. Cheng and E.-W. Huang, BMC Med. Genet., 2017, 18, 19. 55 V. Stepanov, K. Vagaitseva, V. Kharkov, A. Cherednichenko, A. Bocharova, G. Berezina and G. Svyatova, Leg. Med., 2016, 18, 66-71.

56 Z. Su, D. Dias-Santagata, M. Duke, K. Hutchinson, Y.-L. Lin, D. R. Borger, C. H. Chung, P. P. Massion, C. L. VnencakJones, A. J. Lafrate and W. Pao, J. Mol. Diagn., 2011, 13, 7484.

57 L. Yang, H. Sun, D. Chen, M. Lu, J. Wang, F. Xu, L. Hu and J. Xiao, Prenatal Diagn., 2014, 34, 139-144. 